\title{
Good practices in the recovery of ambulation in octogenarian women with hip fractures
}

\author{
DMaría Plaza-Carmona ${ }^{1}$ \\ (iD) Carmen Requena-Hernández² \\ Sonia Jiménez-Mola ${ }^{1}$
}

1. Orthogeriatrics Unit, University Assistance Complex of León, León, Spain. 2. University of León, Léon, Spain.

http://dx.doi.org/10.1590/1806-9282.66.10.1417

\section{SUMMARY}

OBJECTIVE: Determine good recovery practices for ambulation of octogenarian women after hospital discharge after being operated on for hip fracture.

METHODS: Prospective study during the second half of 2019, with 192 women (85.95 \pm 5.1 years) with hip fracture. A medical history, fracture types, complications, surgical treatment, and assessment of the level of ambulation were recorded before and after six months of hospital discharge.

RESULTS: 100 patients lived in the family home and 92 in an institutional center, 68.2\% provided pertrochanteric fracture and a total of 3.7 comorbidities, all of them received spinal anesthesia and were admitted an average of 11.4 days. After six months, the patients showed a significant loss of functional independence with respect to the situation prior to the fracture, both for the ability to wander and for activities of daily living. It is noteworthy that the worst prognosis in the recovery of ambulation has to do with intermediate levels of ambulation and that the functional level of departure influences to a lesser extent than the place where they perform the recovery.

CONCLUSIONS: Age is a factor that influences the recovery of hip fracture, but there are other influential factors since patients who remain in the family home have a better functional prognosis than those who recover in institutionalized centers, after six months of hospital discharge.

KEYWORDS: ambulation; frail elderly; hip fractures; residence.

\section{INTRODUCTION}

It is estimated that the average age individuals who suffer from hip fractures (HF) is $81.4 \pm 8.1$ years, and they are more frequent in women than in men ${ }^{1,2}$. At the same time, it is evident that this type of fracture causes a high comorbidity rate, with an average of 3.7 comorbidities per patient, with a high incidence of signs of cognitive deterioration and a state of acute confusion $^{3,4}$.
Osteopenia is the most serious consequence of osteoporosis, and fractures of the femur represent the highest rate of morbidity and mortality. In addition, osteoporosis fractures represent a great economic burden on health systems ${ }^{5}$. It is estimated that by the year 2050, if the number of fractures continues to grow at the current rate, the incidence of HFs throughout the world will increase by up to 
$310 \%$ in men and $240 \%$ in women, surpassing 4.5 and 6.3 million fractures per year, respectively ${ }^{6,7}$.

In the octogenarian population, the risk factors for this type of fracture are attributed to physical impairments, such as a reduction of visual acuity, peripheral vision, presbycusis, increased reaction time, metabolic changes, increased joint stiffness, increased joint instability, skin changes, and the onset of diseases such as sarcopenia ${ }^{8}$. At the same time, for all purposes, there are other risk factors that are "extrinsic" or environmental, such as poor lighting, obstacles in transition zones, badly placed carpets, lack of architectural barriers, flooring with different levels, among other inappropriate practices ${ }^{9}$.

Good healthcare practices ${ }^{10}$, as well as family support ${ }^{11}$ and social resources, influence the outcomes of maintenance and recovery, after an intervention, of the ambulation of elderly people. In particular, the duration of hospitalization, the type of surgical intervention, recovery through physical therapy sessions, or the absence of the need for commuting to recovery units outside the usual residence act as protective factors for recovery ${ }^{12}$. Therefore, the key is to properly coordinate between the different levels of health and social care to ensure comprehensive care $^{13}$ (Figure 1).

This study is part of a broader research, whose goal is to find evidence of factors that contribute to the preservation of functional independence in the

FIGURE 1. INTERVENTION PROCESSES FOR HFS AND THE DIFFERENT CARE LEVELS IN GERIATRICS (ADAPTED FROM ABIZANDA, 2012).

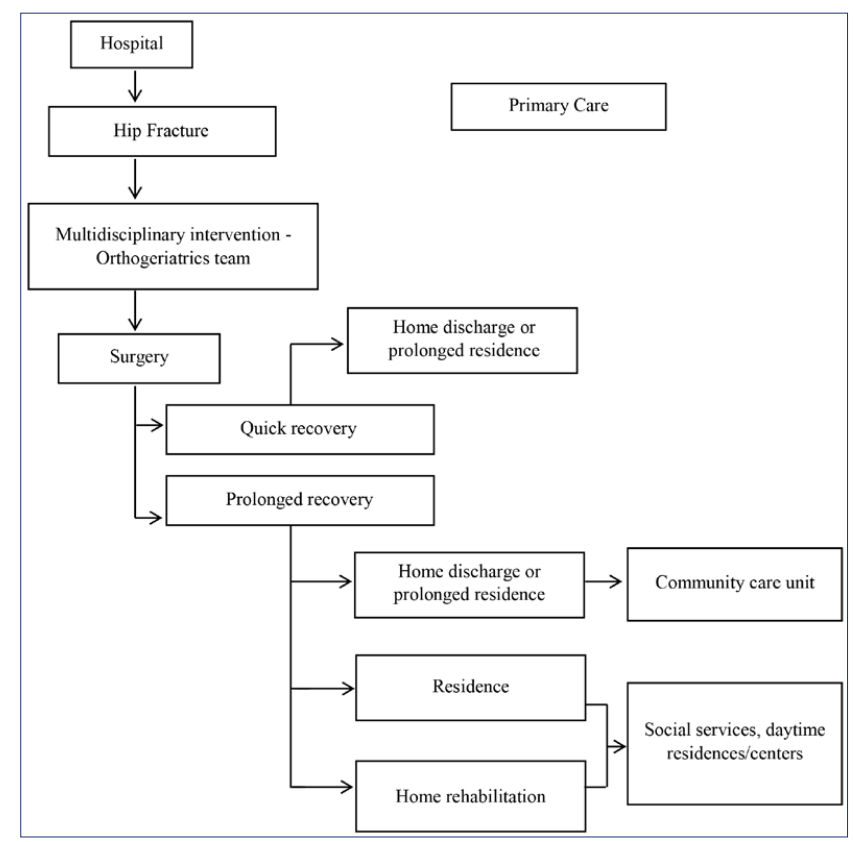

elderly during the final stage of life ${ }^{14}$. In particular, in this research, we aimed to determine the best practices for the recovery of ambulation in octogenarian women after hospital discharge after undergoing surgery for a HF.

\section{METHODS}

This is a prospective, cross-sectional, observational study using a convenience sample. We included 192 women (mean age $85.95 \pm 5.1$ years) who were admitted to the León University Hospital with a diagnose of hip fracture from June to November of 2019.

Exclusion criteria: HF caused by an accident, oncological bone pathologies, and HF secondary to other systemic diseases.

The sociodemographic and clinical data were obtained from the clinical histories. The assessment of the ambulation ability was recorded using the following categories: independent/use of a cane; walker/ use of two canes; a lot of help and not walking.

All participants were informed about the study objectives and procedures and provided their informed consent. The study was approved by the Ethics Committee for Clinical Research of the León Hospital and was carried out according to the ethical standards of the Declaration of Helsinki of 1975 (revised in the $52^{\text {nd }}$ General Assembly of Edinburgh, Scotland, October 2000), the standards of Good Clinical Practice, and in compliance with the Spanish legislation and regulations for human clinical research (Royal Decree 223/2004 for clinical trials).

The data were analyzed using SPSS v 22.0. Inc., Chicago, IL, USA, for Windows, and the significance level was established at $P<0.05$. The descriptive data were presented as mean values, quantitative variables as standard deviation, and qualitative variables as percentages and frequencies. For qualitative results, we used percentages and frequencies, as well as the Chi-square test $\left(\chi^{2}\right)$. The magnitude of the effect was calculated by the coefficient $\mathrm{R}^{2}$. The data analysis showed a normal distribution assessed by the Kolmogorov-Smirnov test.

\section{RESULTS}

Of the 192 octogenarian women (85.95 \pm 5.1 years), 100 lived with their family, and 92 in some institution. A total of $68.2 \%$ presented a peritrochanteric fracture and $31.8 \%$ subcapital. $96.3 \%$ of the patients 
were submitted to surgery, three of them in the emergency service (intervention in the first 24-hours after admission), and $1.7 \%$ had exitus They all received spinal anesthesia; in $62.5 \%$ of the patients intramedullary nails were used, in $21.7 \%$ bipolar partial prosthesis, and in $15.8 \%$ unipolar prosthesis.

Most patients had multiple comorbid conditions at the time of admission and, during their stay, developed other clinical complications and disorders such as delirium (Table 1). $71.1 \%$ of the patients showed independence to walk or needed to use a cane to walk, in comparison with $42.35 \%$ six months after hospital discharge; six of them died after a month and a half.

The results based on groups according to patient domicile highlight the significative differences in functionality and comorbidities at baseline. In particular, regarding depression $\left.\left(X^{2}=7.10 ; \mathrm{p}<.05\right) ; \mathrm{R}^{2}=.011\right)$, dementia $\left(X^{2}=49.10 ; \mathrm{p}<.001 ; \mathrm{R}^{2}=.072\right)$, diabetes $\left.\left(X^{2}=7.34 ; \mathrm{p}<.05\right) ; \mathrm{R}^{2}=.010\right)$, right-sided cerebrovascular accident $\left(X^{2}=15.41 ; \mathrm{p}<.005 ; \mathrm{R}^{2}=.026\right)$, chronic kidney failure $\left(X^{2}=2.31 ; \mathrm{p}<.005 ; \mathrm{R}^{2}=.013\right)$, previous hip fracture hip $\left(X^{2}=7.12 ; \mathrm{p}<.005 ; \mathrm{R}^{2}=.012\right)$, and

TABLE 1. CHI-SQUARED TEST. COMORBIDITIES AND COMPLICATIONS BASED ON THE PLACE OF RESIDENCE BEFORE THE INTERVENTION.

\begin{tabular}{|c|c|c|c|c|c|c|c|}
\hline \multicolumn{8}{|c|}{ COMORBIDITIES } \\
\hline Variable & $\mathrm{N}$ & $\begin{array}{l}(\mathrm{N}=50) \\
\text { Own/family home }\end{array}$ & $\begin{array}{l}(\mathrm{N}=46) \\
\text { Institution }\end{array}$ & $\mathrm{Chi}^{2}$ & gl & $P$ & Size of effect: R2 \\
\hline Cardiopathy & 82 & $74.2 \%$ & $72.4 \%$ & 0.24 & 2 & .795 & .000 \\
\hline Hypertension & 72 & $71.3 \%$ & $71.6 \%$ & 0.16 & 2 & .901 & .000 \\
\hline Depression & 21 & $26.7 \%$ & $28.4 \%$ & 7.10 & 2 & .040 * & .011 \\
\hline Dementia & 21 & $16.2 \%$ & $30.1 \%$ & 49.10 & 2 & $.000^{\star \star}$ & .072 \\
\hline Diabetes & 15 & $17.4 \%$ & $30.4 \%$ & 7.34 & 2 & $.032^{*}$ & .010 \\
\hline Arthrosis & 19 & $18.4 \%$ & $26.5 \%$ & 1.22 & 2 & .620 & .002 \\
\hline Change in sight & 15 & $17.1 \%$ & $18.8 \%$ & 0.99 & 2 & .720 & .002 \\
\hline Cerebrovascular Ac. & 8 & $11.6 \%$ & $20.1 \%$ & 15.41 & 2 & $.005^{*}$ & .026 \\
\hline Chronic kidney failure & 14 & $9.6 \%$ & $18.2 \%$ & 2.31 & 2 & $.022 *$ & .013 \\
\hline COPD & 6 & $12.7 \%$ & $16.4 \%$ & 1.88 & 2 & .460 & .003 \\
\hline Cancer & 12 & $12.1 \%$ & $18.3 \%$ & 2.72 & 2 & .071 & .013 \\
\hline Multiple falls & 10 & $10.6 \%$ & $15.4 \%$ & 3.10 & 2 & .052 & .004 \\
\hline Anemia & 2 & $7.1 \%$ & $15.1 \%$ & 6.21 & 2 & .054 & .008 \\
\hline Osteoporosis & 6 & $9.4 \%$ & $13.8 \%$ & 6.28 & 2 & .053 & .015 \\
\hline Previous hip fracture & 4 & $6.3 \%$ & $15.4 \%$ & 7.12 & 2 & $.005^{\star \star}$ & .012 \\
\hline Parkinson's Disease & 2 & $0.1 \%$ & $6.1 \%$ & 10.21 & 2 & $.003^{\star \star}$ & .024 \\
\hline Dysphagia & 2 & $0.4 \%$ & $4.8 \%$ & -- & -- & -- & -- \\
\hline \multicolumn{8}{|c|}{ COMPLICATIONS } \\
\hline & $\mathrm{N}$ & $\begin{array}{l}(\mathrm{N}=50) \\
\text { Own/family home }\end{array}$ & $\begin{array}{l}(\mathrm{N}=46) \\
\text { Institution }\end{array}$ & $\mathrm{Chi}^{2}$ & gl & $P$ & Size of effect: R2 \\
\hline Anemia & 87 & $84.3 \%$ & $90.2 \%$ & 5.52 & 2 & $.030^{*}$ & .010 \\
\hline Transfusion & 46 & $38.0 \%$ & $34.2 \%$ & 3.62 & 2 & .310 & .005 \\
\hline Acute confusion syndrome/Delirium & 36 & $37.3 \%$ & $33.2 \%$ & 1.55 & 2 & .457 & .006 \\
\hline Constipation & 26 & $23.5 \%$ & $26.2 \%$ & 2.06 & 2 & .322 & .004 \\
\hline Changed kidney function & 8 & $13.4 \%$ & $23.7 \%$ & 5.02 & 2 & .051 & .007 \\
\hline Urinary tract infection & 34 & $16.3 \%$ & $12.4 \%$ & 4.12 & 2 & .143 & .006 \\
\hline Respiratory infection/failure & 12 & $12.6 \%$ & $17.6 \%$ & 3.86 & 2 & .141 & .005 \\
\hline Malnourishment & 11 & $13.7 \%$ & $15.1 \%$ & 1.02 & 2 & .473 & .002 \\
\hline Heart failure & 6 & $9.1 \%$ & $12.1 \%$ & 2.37 & 2 & .212 & .006 \\
\hline Acute urinary retention & 5 & $9.0 \%$ & $11.4 \%$ & 0.50 & 2 & .621 & .001 \\
\hline Ischemic heart disease & 2 & $7.2 \%$ & $4.3 \%$ & 2.62 & 2 & .261 & .005 \\
\hline Exitus & 3 & $3.1 \%$ & $12.4 \%$ & 7.81 & 2 & $.023^{*}$ & .014 \\
\hline Pressure ulcers & 3 & $4.1 \%$ & $2.9 \%$ & 0.90 & 2 & $.625^{\text {NS }}$ & .002 \\
\hline Infection of Qx wound & 4 & $0.9 \%$ & $0 \%$ & -- & -- & -- & -- \\
\hline Cerebrovascular Ac. & 2 & $0.9 \%$ & $0 \%$ & -- & -- & -- & -- \\
\hline PVThrombosis & 2 & $0 \%$ & $1.4 \%$ & -- & -- & -- & -- \\
\hline
\end{tabular}


Parkinson's disease $\left(X^{2}=10.21 ; \mathrm{p}<.005 ; \mathrm{R}^{2}=.024\right)$. In addition, we found that the type of anesthesia used produces significant differences in functionality and mobility after the intervention, with better results from local anesthesia (spinal) $\left(X^{2}=4.80 ; \mathrm{p}<.002\right.$; $\mathrm{R}^{2}=.038$ ) (Table 2).

Complications and characteristics at hospital admission and discharge are presented in Table 1, according to the place of residence of patients. There are statistically significant differences in favor of the group who lived with a family member in variables such as anemia $\left(X^{2}=5.52 ; \mathrm{p}<.005 \mathrm{R}^{2}=.010\right)$ or exitus $\left(X^{2}=7.81 ; \mathrm{p}<.005 ; \mathrm{R}^{2}=.014\right)$; for all other variables there were no statistically significant measurements based on the place of residence $(P>.05)$.

As shown in Table 2, there are significant differences in the recovery of the ambulation ability depending on the patients' place of residence $\left(X^{2}=17.32 ; \mathrm{p}<.004 ; \mathrm{R}^{2}=.042\right)$. Finally, age, regardless of the place of residence, is linked to the ambulatory ability after an intervention due to a HF. Our data make it clear that nonagenarian patients have a worse recovery of ambulation (Table 2).

\section{TABLE 2}

\begin{tabular}{l|l|l} 
Age ranges & $\begin{array}{l}\text { General } \\
\text { Population (IU) }\end{array}$ & $\begin{array}{l}\text { Risk Popu- } \\
\text { lation (IU) }\end{array}$ \\
\hline 0-12 months & 400 & $400-1,000$ \\
\hline $1-8$ years & 400 & $600-1,000$ \\
\hline $9-18$ years & 600 & $600-1,000$ \\
\hline $19-70$ years & 600 & $1,500-2,000$ \\
\hline$>70$ years & 800 & $1,500-2,000$ \\
\hline Pregnant women 14-18 years & 600 & $600-1000$ \\
\hline Pregnant women $>18$ years & 600 & $1,500-2,000$ \\
\hline Breastfeeding women $14-18$ years & 600 & $600-1,000$ \\
\hline Breastfeeding women $>18$ years & 600 & $1,500-2,000$ \\
\hline & &
\end{tabular}

$\mathrm{IU}=$ International Units.

\section{DISCUSSION}

The results make it clear that the place of residence of octogenarians (with family or some institution) is correlated with the type of clinical and functional comorbidity before, during, and after discharge from hospital. After six months from hospital discharge, the ambulatory had better recovery in the group of women who live with their families. In particular, patients who came from some institution and returned to it after hospital discharge had up to $64 \%$ of loss of independent ambulation or with the use of a cane, compared to only $32.8 \%$ of those who returned to their family home.

Age is a determining factor for the length of hospital stay, which is shorter for younger patients, in agreement with the findings of other studies ${ }^{15}$. The mean hospital stay was 11.44 days, in line with the research by Bellas, which found a stay between ten and fourteen days,${ }^{16}$ and slightly longer than the average stay recently of ten days found by Castilla y León ${ }^{14}$. Despite that, early surgery is recommended for hip fractures, within the first 24-36 hours; the pre-surgical stay for patients in this study was 5.78 days, higher than the national average (4.31 days) ${ }^{17}$ and the average found by Castilla y León (3 days) ${ }^{14}$. Patients who received general anesthesia (21.7\%) spent an average of 10.4 days hospitalized and presented a greater number of complications compared to patients who received local anesthesia (74.2\%), who had an average of 8.2 days and showed a better recovery of independent functionality, data similar to those obtained in other studies ${ }^{18}$. Overall, in the studies reviewed, it is recommended to minimize the overall days of hospital stay, surgical and post-surgical, to avoid increasing the average stay, with a higher risk of infection of the joint prosthesis, an increase of readmissions during the first month after discharge, and increased health costs ${ }^{6}$.

Regarding the functional anatomy by groups of patients, the data show a clear advantage of women who remain home before and after the hospital stay. In this sense, according to the study by Sanclemente-Boli and collaborators, the better recovery of ambulation in these patients can be explained by the support provided by a family caregiver ${ }^{19}$. The family caregiver receives instructions from the orthogeriatric team, in which nurses play a fundamental role, also performing household monitoring, which contributes to the reduction of hospital complications ${ }^{20}$. However, institutionalized patients do not have the advantage of having a family member as a permanent caregiver, which is essential in the recovery of ambulation. In addition, the physical therapy rehabilitation received by these women is insufficient since some institutions where they reside have an on-site physical therapist for only 5 hours a week to service an average of 50 residents. However, patients who live with their families receive customized rehabilitation at the hospital center, and the family caregiver who accompanies them receives instructions on exercises to complete at home. 


\section{CONCLUSIONS}

Age may be an influencing factor in the recovery of older patients. However, there are other influencing factors, such as their place of residence and follow-up. Patients who live with their families have a family member as a permanent caregiver, which positively impacts the recovery of the ambulation ability in patients with a HF six months after hospital discharge. In future research, it would be interesting to draw up a guide for good infirmary practices to handle the social and health problems that hinder a good recovery of patients with HFs.

\section{Conflict of interests}

The authors declare there are no conflicts of interest.

\section{Author's Contribution}

MPC: made substantial contributions to the project concept and design, data acquisition, analysis, and interpretation; CRH: made substantial contributions to the project concept and design, data analysis, and interpretation; SJM: made substantial contributions to the project concept and design, data acquisition, analysis, and interpretation.

\section{RESUMO}

OBJETIVO: Determinar boas práticas para a recuperação da ambulação de octogenárias posterior à alta hospitalar após cirurgia por fratura da pelve.

METODOLOGIA: Um estudo prospectivo realizado no segundo semestre de $2019 \mathrm{com} 192$ mulheres (85,95 $\pm 5,1$ anos) com fratura da pelve. O histórico médico, tipo de fratura, complicações, tratamento cirúrgico, e avaliação do nível de ambulação foram registrados antes da alta hospitalar e após seis meses.

RESULTADOS: De todas as pacientes, 100 viviam com a família e 92 em alguma instituição, 68.2\% tinham fratura peritrocantérica e uma média de 3,7 comorbidades; todas receberam anastesia espinhal e ficaram internadas por 11,4 dias em média. Após seis meses, as pacientes apresentaram uma perda significativa da independência funcional em relação à situação anterior à fratura, tanto em relação à capacidade de ambulação e atividades cotidianas. É importante ressaltar que o prognóstico negativo em relação à recuperação da ambulação está relacionado a níveis intermediários de ambulação e que o nível funcional de saída tem menor influência do que o local onde a recuperação é feita.

CONCLUSÃO: A idade é um fator que influencia a recuperação de fraturas da pelve. Porém, há outros fatores com influência, já que as pacientes que ficam com familiares têm um prognostico funcional melhor do que aquelas que se recuperam em instituições, após seis meses da alta hospitalar.

PALAVRAS-CHAVE: ambulação; idosos frágeis; fraturas da pelve; residência.

\section{REFERENCES}

1. Herrera A, Martínez A, Fernández L, Gil E, Moreno A. Epidemiology of osteoporotic hip fractures in Spain. Int Orthop. 2006;30:11-4.

2. Jayeun K, Soong-Nang J, Jae-Young L. Pre-Existing Disability and Its Risk of Fragility Hip Fracture in Older Adults. Int J Environ Res Public Health. 2019;16:1237.

3. Ireland A, Kelly P, Cumming RG. Total hospital stay for hip fracture: measuring the variations due to pre-fracture residence, rehabilitation, complications and comorbidities. BMC Health Serv Res. 2015;15(1):17.

4. Jiménez-Mola S, Calvo-Lobo C, Idoate-Gil I, Seco-Calvo |. Functionality, comorbidity, complication \& surgery of hip fracture in older adults by age distribution. Rev Assoc Med Bras. 2017;64(5):420-7.

5. Tarazona-Santabalbina F, Belenguer-Varea A, Rovira Daudi E, Salcedo Mahiques E, Cuesta Peredó D, Doménech-Pascual J, et al. Severity of cognitive impairment as a prognostic factor for mortality and functional recovery of geriatric patients with hip fracture. Geriatr Gerontol Int. 2015;15(3):289-95

6. Bartra A, Caeiro JR, Mesa-Ramos M, Etxebarría-Foronda, I. Montejo J, Carpintero P, Sorio-Vilela F, et al. Coste de la fractura de cadera osteoporótica en España por comunidad autónoma. Rev Española Cirugía Ortopédica y Traumatol. 2019;63(1):56-68.
7. Sáez-López P, Etxebarria-Foronda, I. Lampre MPM, García NA, Hernández NS. Efficacy, cost, and aspects to take into account in the treatment of osteoporosis in the elderly. Rev Esp Geriatr Gerontol. 2019;54(3):156-67.

8. Lobo E, Marcos G, Santabárbara J, Salvador-Rosés H, Lobo-Escolar L, De la Cámara $\mathrm{C}$, et al. Gender differences in the incidence of and risk factors for hip fracture:A 16-year longitudinal study in a southern European population. Maturitas. 2017;97:38-43.

9. Abizanda-Soler P, Romero-Rizos L. Medicina Geriátrica. Una aproximación basada en problemas. Barcelona: Elservier; 2012

10. Jiménez-Sánchez, MD Córcoles-Jiménez $M$, del Egido-Fernández, MA Villada-Munera A, Candel-Parra E, Moreno-Moreno M. Análisis de las caídas que producen fractura de cadera en ancianos. Enfermería Clínica. 2011;21(3):143-50.

11. Serra |, Vidán M, García D, Marañon E, Álvarez L, Moreno A, et al. Modelo de tratamiento secuencial ortopédicogeriátrico y rehabilitador en ancianos con fractura de cadera. Rev Esp Geriatr Gerontol. 2000;35(1):42-50.

12. Zuckerman |D, Koval K|, Aharonoff GB, Hiebert R, Skovron ML. A functional recovery score for elderly hip fracture patients: I. Development. J Orthop Trauma. 14AD;1:20-5. 
13. Lee YK, Lee YJ, Ha YC, Koo KH. Five-year relative survival of patients with osteoporotic hip fracture. J Clin Endocrinol Metab. 2014;99(1):97-100.

14. Montalvo J, Pérez P, Vega A, Alarcón T. La unidad de ortogeriatría de agudos. Evaluación de su efecto en el curso clínico de los pacientes con fractura de cadera y estimación de su impacto económico. Rev Esp Geriatr Gerontol. 2011;46(4):193-9.

15. Plaza-Carmona M, Requena-Hernández C, Ilia R, López-Fernández V. Relationships between unstructured time, leisure and cognitive functions in the elderly. Eur J Educ Psychol. 2015;8(2):60-7.

16. Singer B, McLauchlan G, Robinson CM, Christie |. Epidemiology of fractures in 15000 adults. J Bone Joint Surg Br. 1998;80-B(2):243-8.
17. Vellas B. Aspects geriatriques de les fractures des sujets de plus de 80 ans. Rev Chir Orthopédique Traumatol. 2003;89(2):142-4.

18. Bennett A, Li H, Patel A, Kang K, Gupta P, Choueka I, et al. Retrospective Analysis of Geriatric Patients Undergoing Hip Fracture Surgery: Delaying Surgery Is Associated With Increased Morbidity, Mortality, and Length of Stay. Geriatr Orthop Surg Rehabil. 2018;9:215145931879526.

19. Scarano K, Philp F, Westrick E, Altman G, Altman D. Evaluating Postoperative Complications and Outcomes of Orthopedic Fracture Repair in Nonagenarian Patients. Geriatr Orthop Surg Rehabil. 2018;2:2151459318758106.

20. Kim |, Jang S, Lim |. Pre-existing disability and its risk of fragility hip fracture in older adults. Int J Environ Res Public Health. 2019;16(17):1237. 